University of Nebraska - Lincoln

DigitalCommons@University of Nebraska - Lincoln

\title{
The Disability Screening Process and the Labor Market Behavior of Accepted and Rejected Applicants: Evidence from the Health and Retirement Study
}

Seth H. Giertz

University of Nebraska-Lincoln, sgiertz2@unl.edu

Jeffrey D. Kubik

Syracuse University, jdkubik@maxwell.syr.edu

Follow this and additional works at: https://digitalcommons.unl.edu/econfacpub

Part of the Economic Policy Commons, Labor Economics Commons, Public Economics Commons, and the Public Policy Commons

Giertz, Seth H. and Kubik, Jeffrey D., "The Disability Screening Process and the Labor Market Behavior of Accepted and Rejected Applicants: Evidence from the Health and Retirement Study" (2011). Economics Department Faculty Publications. 69.

https://digitalcommons.unl.edu/econfacpub/69

This Article is brought to you for free and open access by the Economics Department at DigitalCommons@University of Nebraska - Lincoln. It has been accepted for inclusion in Economics Department Faculty Publications by an authorized administrator of DigitalCommons@University of Nebraska - Lincoln. 
Published in Journal of Labor Research (2011); doi: 10.1007/s12122-011-9110-0

Copyright (C) 2011 Springer Science+Business Media, LLC. Used by permission.

Published online May 3, 2011.

The authors thank Dan Black and Jan Ondrich for helpful comments. This research was supported, in part, by the Center for Retirement Research at Boston College pursuant to a grant from the U.S. Social Security Administration funded as part of the Retirement Research Consortium.

\title{
The Disability Screening Process and the Labor Market Behavior of Accepted and Rejected Applicants: Evidence from the Health and Retirement Study
}

\author{
Seth H. Giertz \\ Department of Economics, University of Nebraska-Lincoln, CBA 368, \\ P.O. Box 880489, Lincoln, NE 68588, USA; email sgiertz2@unl.edu \\ Jeffrey D. Kubik \\ Center for Policy Research, Syracuse University, 426 Eggers Hall, \\ Syracuse, NY 13244-1020, USA; email jdkubik@maxwell.syr.edu
}

\begin{abstract}
This paper uses Social Security earnings records linked to data from the Health and Retirement Study to examine the labor market behavior of rejected and accepted disability applicants prior to their application. We find that rejected applicants have substantially lower earnings and labor force participation rates during the decade prior to application than beneficiaries. Also, we find some evidence of a divergence between these groups, with rejected applicants leaving the labor force at a faster rate than beneficiaries as their application date approaches. One interpretation of these results is that the disability screening process on average separates those who are at least partially motivated by adverse economic circumstances when applying for disability benefits from other applicants.
\end{abstract}

Keywords: Social Security, disability insurance, disability screening process

\section{Introduction}

Applications to United States federal disability programs have grown considerably in recent decades. In 2005, over 2.12 million individuals applied for benefits from the Social Security Disability Insurance (DI) program (Social Security Administration 2006); the Supplemental Security Income (SSI) program received nearly a 1.1 million new applications for benefits from working age adults 
(Brooks 2007). For DI, this is over five times the number of applications in 1960 and almost twice the 1990 figure.

In addition to the burdens that the rise in DI applications placed on the screening process, it has also resulted in rapid growth of the program, both in terms of expenditures and beneficiaries. After stabilizing through much of the 1980s, the number of working age beneficiaries has more than doubled since 1990 (from 3 million to 6.5 million in 2005). Payments to working age beneficiaries were $\$ 85.4$ billion in 2005 and continue to grow faster than inflation. Autor and Duggan (2006) argue that changes to the DI screening process are a key factor contributing to the program's rapid growth. They point to 1984 reforms and subsequent changes that liberalized the eligibility criteria for DI by expanding the number of qualifying conditions to include some that are difficult to authenticate (such as back pain and mental illness) and by amending the rules of evidence so that they became more favorable to applicants. ${ }^{1}$ In addition, they point to increases in the replacement rate (i.e., the ratio of potential benefits to earnings) for low-skilled workers as another driving factor. These two factors are interrelated. The reform gave workers more discretion as to whether to shift onto the DI rolls, while the rising replacement rate (for low-skilled workers) gave them an increasing incentive to do so.

The Social Security Administration (SSA) must process DI applications to determine if applicants meet the work and health requirements of the programs. Individuals must demonstrate in their applications that they have a health condition that is severe enough to prevent them from performing market work for at least 1 year. Evaluating these claims is expensive. The costs to SSA of administering the DI program (\$2.32 billion) were over 78\% as high in 2005 as SSA's costs for administering the much larger old-age and survivors program (\$2.96 billion). In fact, when scaled by benefits paid, administrative costs are 3.9 times greater for the DI program (2.7\% of benefits) than for the old age and survivors program ( $0.7 \%$ of benefits).

Despite the large resources used to evaluate these disability applications, applicants often express a great deal of dissatisfaction with the screening process. Much of this dissatisfaction arises because of the high denial rate of applications. In 2005, nearly 1.3 million (or nearly $61 \%$ of) applications for DI were denied by SSA. In recent decades, denial rates have averaged $55 \%$; over that time, an average of three-quarters of one million individuals have been denied DI benefits each year. Denial rates of SSI applications over this time period have been even higher. Denied disability applicants can either drop their claims to disability benefits, or embark on a long and potentially costly appeals process.

Because of the uncertainty in accurately determining an applicant's work capacity, there is disagreement about whether SSA successfully identifies whether applicants meet the health standards for receipt of disability benefits. Some lament that the process is too strict and that many denied applicants are deserving of benefits, while others argue that the screen is too lax and that many who are capable of working abuse the program. In any event, Autor and Duggan (2006) con-

1. The 1984 reforms represent a classic tradeoff between Type I and Type II error. The reform lowered Type I error, the likelihood of rejecting applicants who are truly disabled at the expense of Type II error, the likelihood of accepting applicants who should not qualify. 
clude that the system is "broken" and in need of reform. They argue that changes to the screening process since 1984 have turned the program into "a nonemployability insurance program for a subset of beneficiaries."

Little work has been done investigating the characteristics of denied and accepted disability applicants in order to help determine the efficacy of SSA screening process. This paper examines the pre-application labor market histories of accepted and rejected DI and SSI applicants. Administrative earnings records from the Health and Retirement Study are used to measure the trends in work behavior of these groups in the years leading up to a disability application.

We find considerable differences in the labor force behavior of rejected and accepted male disability applicants in the years leading up to application. After controlling for observable demographic and health characteristics, rejected applicants have substantially lower earnings and labor force participation rates prior to application. On average, the labor force participation rate of denied applicants is about $10 \%$ lower before application than for similar beneficiaries. For a group who are primarily DI applicants (some are applying for SSI disability benefits), there is evidence of a divergence between the rejected applicants and beneficiaries as the application date approaches. Rejected applicants earn on average $8.5 \%$ less than beneficiaries 6 years prior to application, but almost $22 \%$ less just prior to application.

Our analysis suggests that rejected and accepted disability applicants have different labor market experiences prior to application, with the rejected applicants performing worse economically. This finding is consistent with a couple of scenarios. First, the SSA screening process might be perverse in that healthier applicants (who were able to work considerably in the years before application) are granted benefits and less healthy applicants (who were unable to work much before application) are denied.

A more plausible scenario is that SSA screening process on average separates those who are at least partially motivated by economic considerations when applying for disability benefits from other applicants. For a worker who has experienced a severe negative employment shock, for example a layoff or a decline in wages because he or she works in a declining industry, disability benefit application might be attractive even if the worker's health problems do not completely preclude employment. Studies such as Black et al. (2002), Autor and Duggan (2003), Duggan and Imberman (2008) and von Wachter et al. (forthcoming) find that disability application decisions are sensitive to economic circumstances. Geographic areas and groups that experience large declines in market opportunities are more likely to apply for benefits. Our findings show that, among applicants for disability benefits, rejection rates are higher for those whose earnings and labor force participation declines more sharply in the years leading up to application. While we do not have data on geographic or industry shocks, our evidence is consistent with findings in the literature that that disability applicants are motivated by adverse employment shocks. While economic circumstances may be an important factor in the application decision, this paper leaves the work disincentive effects of the DI program an open question. ${ }^{2}$

2. For example, even if DI induces able-bodied people to apply for benefits, it does not necessarily imply that these people would remain in the labor force absent DI. 


\section{Institutional Background}

Social Security Disability Insurance (DI) and Supplemental Security Income (SSI) provide cash assistance to people who are unable to work because of health problems. ${ }^{3}$ DI was added to Social Security in 1957 and protects workers under age 65 who are unable "to engage in substantial gainful activity by reason of physical or mental impairment" for a period determined to last at least 12 months or until death. SSI was begun in 1974 in order to provide assistance to those who do not meet the work requirements for DI; it covers children, the aged, as well as working age adults. DI is an insurance system for workers; whereas, SSI is a means-tested welfare program. In order to qualify for DI, individuals must pay into the system (via the FICA tax) for a specified number of quarters, depending on age. SSI provides benefits to the disabled but, in place of work histories, requires recipients to earn below the Federal Benefit Rate ${ }^{4}$ and have assets of less than $\$ 2000$ for individuals and $\$ 3000$ for couples.

Both programs are large both as measured by the number of recipients and overall annual expenditures. In 2005, DI had 8.3 million beneficiaries receiving $\$ 85.4$ billion in benefits; SSI paid nearly $\$ 23.1$ billion in benefits to 4.1 million working age adults. DI benefit calculations are made just as they are for Social Security's retirement program, except that benefits are not actuarially reduced as they are for individuals retiring before age 65. SSI benefits are generally lower, but vary depending on state supplementation.

The application processes for DI and SSI are very similar. In order to receive DI, applicants must be out of the labor force for a minimum of 5 months. For SSI, the earnings limit effectively rules out more than nominal labor market activity. Application decisions for both programs are based on the review of the applicant's medical conditions by state boards. Both programs use the same health criteria; in order to qualify, an individual must have a condition that prevents him from working anywhere in the economy. The programs make no allowance for being "partially" disabled. Denied applicants have a number of appeals options. First, to the state agency and then to an Administrative Law Judge who is independent of the state boards. Should these options fail, the next step is to the SSA Appeals Council and finally to the Federal courts. Many initially rejected applicants are eventually accepted on appeal.

While much research has focused on disability beneficiaries and their potential for work, there is a small but growing literature on rejected applicants and the disability screening process. ${ }^{5}$ Some work has attempted to evaluate the quality of the SSA screening process. For example, Nagi (1969) and Smith and Lilienfeld (1971) find that reconsideration of SSA disability decisions by either the same state board 1 year later or a separate team of medical experts reveal substantial Type I and Type II errors. These studies find that as many as $20 \%$ of all denials and an equivalent number of allowances would be reversed by another evalua-

4 In 2006, the Federal Benefit Rate was $\$ 603$ for individuals and $\$ 904$ for couples.

5 See Bound and Burkhauser (1999) for a review of the literature on government disability programs.

3 Another important benefit to disability recipients is medical insurance. DI recipients are automatically enrolled in Medicare after being in the program for 2 years. SSI recipients are generally enrolled in Medicaid immediately. 
tion. Gruber and Kubik (1997) examine the dramatic increase in DI rejection rates in the late 1970s. They find that the increasing stringency resulted in greater labor force participation for 45-64 year old males, with increases that were much larger for those who appeared to be more able. Other work has measured the health and demographic characteristics that are associated with disability program application, appeals and awards. See, for example, Lahiri et al. (1995), Benitez-Silva et al. (1999) and Kreider and Riphahn (1999).

Bound (1989) and Chen and van der Klaauw (2008) both use survey data to compare the health and economic behavior of rejected and accepted DI applicants. Additionally, von Wachter et al. (forthcoming) examine similar questions using administrative Social Security records. Bound examines applicants from the 1970s, while Chen and van der Klaauw (2008) focus primarily on the 1990s. ${ }^{6}$ At the time of the surveys, rejected applicants were employed at less than one-half the rate of the overall population. Bound believes that rejected DI applicants are in at least somewhat better health than accepted applicants. He uses the work behavior of these rejected applicants as a proxy (or an upper bound) for what the behavior of accepted applicants would have been had no DI program existed. Because rejected applicants are for the most part not working, he concludes that an even smaller percentage of accepted applicants would be working had no DI program been in place, assuming that beneficiaries are in worse health than rejected DI applicants. ${ }^{7}$

Others have argued that despite being in better health, the behavior of rejected applicants may actually understate the counterfactual behavior of accepted applicants. Chen and van der Klaauw write that "rejected applicants and beneficiaries may on average differ not only in their average health but also in other characteristics, such as their average pre-application earnings, work histories, age and education level. Moreover, they may differ in their preferences for working." They also note Parsons' (1991) contention that the application process may lower labor force participation even for rejected applicants, since many of these people may stay out of the labor force in order to appeal their decision or to reapply. Additionally, not working during the application process may reduce applicants' earnings opportunities, thus also lowering their labor force participation rate.

Chen and van der Klaauw report statistically significant demographic differences between rejected and accepted applicants, suggesting that the behavior of rejected applicants may not be an upper bound for the counterfactual behavior of accepted applicants. For example, rejected applicants are more likely female and non-white, characteristics that are often correlated with weaker attachment to the labor force. However, despite these differences, Chen and van der Klaauw conclude that Bound's approach likely provides a reasonable upper bound for the counterfactual behavior of accepted applicants. Using a sophisticated approach that controls for differences between rejected and accepted applicants, they estimate that DI reduces the labor supply of beneficiaries by 20 percentage points versus an estimated 15 percentage points when employing Bounds' technique. Nonetheless, estimates from both approaches suggest that most accepted applicants would not be working, even if DI did not exist.

6.While Bound (and most other studies) focuses on male applicants, Chen and van der Klaauw include both male and female applicants in their analysis.

7. See Parsons (1991) and Bound (1991) for a debate about the reliability of this empirical strategy. 
Von Wachter et al. (forthcoming) generally confirm that Bound's findings for older DI applicants holds for their data spanning from 1978 to 2004. They report that earnings for applicants (and especially rejected applicants) have declined over time when compared to non-applicants. Additionally, they find that rejected applicants are more likely to have spells where they are not employed (or have drops in earnings), whereas accepted applicants have more stable earnings histories, with a sharp decline in the year before applying to DI. ${ }^{8}$

\section{Data}

The Health and Retirement Study (HRS) is comprised of data on 7,702 United States households whose primary respondent was between ages 51 and 61 in 1992, when the first survey was conducted. Subsequent surveys have been carried out every other year since the initial 1992 wave. In addition to economic variables, the HRS includes detailed information on family structure, health, and geographic information on the household head and spouse's parents, children, and siblings. Important variables from the HRS used in this paper include the date of disability application (for either DI or SSI), as well as a number of demographic characteristics such as education, age, race, marital histories, and gender. The most important feature of the HRS data for our work is the ability to link respondents to administrative earnings records from the SSA. ${ }^{9}$ The records include covered earnings under Social Security for the years 1951 through 1991.

In each wave of the HRS, individuals are asked not only about their health, but also whether they have applied for DI or SSI since the previous interview date. Additionally, for the first interview date (1992), individuals are asked if they have ever applied to either program. Questions are then asked as to the date and outcome of the application. Initially denied applicants are asked whether they appealed their decision or reapplied to the program. For those who applied for a disability program, we match the health, demographic and application information with the Social Security administrative earnings records in order to create a panel with the applicant's labor market participation and earnings observations for each of the 10 years leading up to his application.

The resulting data set contains 489 males with applications through 1992.10 (By contrast, there are 4,328 males with earnings records but no applications.) Of these 489 applicants, $74 \%$ were accepted by the 1996 survey date, including those accepted on appeal or reapplication. Tables 1 and 2 provide summary statistics on the labor market, demographic and health characteristics of the male disability applicants. The earnings and labor force participation rates of disability applicants decline sharply over the 10 years preceding application. Throughout this period, average earnings drop by nearly $\$ 6400$ (or $28.6 \%$ ) and labor force participation drops 12.4 percentage points (or $14.9 \%) .{ }^{11}$

8. They also look at the health characteristics of their sample. However, for the most part, their health information is self-reported with the disability application.

9. Approximately $85 \%$ of the overall HRS sample consented to this matching.

10. Also, another 145 have applications prior to 1992, but are excluded from the sample because the exact year of application is not observed.

11. Note that all earnings are in 1999 dollars. 
Table 1. Demographic characteristics of male disability applicants

\begin{tabular}{|c|c|c|}
\hline & $\mathrm{N}$ & Percent \\
\hline $1996 \mathrm{LFP}^{\mathrm{a}}$ & 489 & 9.2 \\
\hline Accepted by 1996 & 362 & 74.0 \\
\hline \multicolumn{3}{|l|}{ Race } \\
\hline White & 306 & 62.6 \\
\hline Black & 127 & 26.0 \\
\hline Hispanic & 49 & 10.0 \\
\hline Other & 7 & 1.4 \\
\hline \multicolumn{3}{|l|}{ Education } \\
\hline Less than HS & 229 & 46.8 \\
\hline HS Grad or GED & 221 & 45.2 \\
\hline Assoc. Degree & 9 & 1.8 \\
\hline Bachelors Degree & 21 & 4.3 \\
\hline Professional Degree & 9 & 1.8 \\
\hline \multicolumn{3}{|l|}{ Age at Application (Average Age $=48$ ) } \\
\hline 30 or Younger & 16 & 3.3 \\
\hline $31-40$ & 52 & 10.6 \\
\hline $41-50$ & 155 & 31.7 \\
\hline $51-60$ & 235 & 48.1 \\
\hline $61 \& U p$ & 31 & 6.3 \\
\hline \multicolumn{3}{|l|}{ Health } \\
\hline Cancers \& tumors; skin conditions & 19 & 3.9 \\
\hline Musculoskeletal system \& connective tissue & 221 & 45.2 \\
\hline Heart, circulatory \& blood conditions & 213 & 43.6 \\
\hline Respiratory system conditions & 63 & 12.9 \\
\hline Endocrine, metabolic \& nutritional & 48 & 9.8 \\
\hline Digestive system & 34 & 7.0 \\
\hline Neurological \& sensory & 48 & 9.8 \\
\hline Reproductive system \& prostate & 1 & 0.2 \\
\hline Emotional \& psychological & 27 & 5.5 \\
\hline Miscellaneous & 24 & 4.9 \\
\hline Other symptoms & 7 & 1.4 \\
\hline
\end{tabular}

a. This is the self-reported labor force participation rate from the 1996 HRS. Note that $57 \%$ of males with no application reported being in the labor force

Table 3 breaks down these summary statistics separately for denied and accepted applicants. As in Bound (1989) and Chen and van der Klaauw (2008), we find that few denied disability applicants are in the labor force at the time 
Table 2. Labor force activity of disability applicants the decade before application

\begin{tabular}{ccc} 
Years to Application & Average Earnings $^{\mathrm{a}}$ & LFP Rate $^{\mathrm{b}}$ \\
\hline 10 & 22,211 & 83.4 \\
9 & 21,702 & 82.2 \\
8 & 22,379 & 82.5 \\
7 & 22,640 & 82.3 \\
6 & 22,086 & 80.3 \\
5 & 22,442 & 79.9 \\
4 & 21,531 & 79.7 \\
3 & 20,856 & 77.1 \\
2 & 18,729 & 77.5 \\
1 & 15,848 & 71.0 \\
\hline
\end{tabular}

a. Earnings are in 1999 dollars

b. Anyone with positive earnings in a given year is considered in the labor force

of the survey; just $22.4 \%$ of denied applicants report working. ${ }^{12}$ For accepted applicants, the number is $4.6 \% .{ }^{13}$ While whites apply for benefits at a much lower rate than blacks and Hispanics, they also have lower acceptance rates than these other groups. $78.6 \%$ of applicants with a less than high school education are accepted, the highest rate of any education group. Those ages 31-40 are the most likely to be accepted at $86.5 \%$. Accepted applicants are much more likely than denied applicants to have heart, circulatory, or blood conditions, but many of the other health conditions have similar acceptance rates.

\section{Estimation}

In this section, the year of application is used as a reference point for examining the behavior of rejected and accepted applicants for the 10 years leading up to application. Both labor force participation rates and earnings are examined: first by a raw comparison of rejected and accepted applicants and then with an econometric analysis, controlling for observed differences between the groups.

Figures 1 and 2 present earnings and labor force participation rates for accepted and rejected applicants during the 10 years leading up to application without any adjustments for observable health or demographic characteristics. ${ }^{14}$ The graphs show a substantial reduction in work activity by both rejected and accepted applicants as the application date approaches. They also suggest that re-

12. Recall that Bound's sample spans the 1970s, whereas Chen and van der Klaauw use data for the 1990s and data from von Wachter et al. (forthcoming) span from 1978 to 2004.

13. By contrast, $57 \%$ of those without disability applications reporting being in the labor force. By 1996, the primary respondent from each household is between age 55 and 65, so a number of people in this group are retired.

14. Again, those with any labor earnings are considered in the labor force. 
Table 3. Characteristics of denied and accepted disability applicants

\begin{tabular}{|c|c|c|c|c|}
\hline & $\mathrm{N}$ & $\begin{array}{l}\text { Denied } \\
(\mathrm{pct})^{\mathrm{a}}\end{array}$ & $\begin{array}{l}\text { Accepted } \\
\quad(p c t)^{\mathrm{a}}\end{array}$ & $\begin{array}{l}\text { Acceptance } \\
\text { Rate }^{c}\end{array}$ \\
\hline $1996 \mathrm{LFP}^{\mathrm{d}}$ & 489 & 22.4 & 4.6 & \\
\hline Accepted by 1996 & 362 & & & 74.0 \\
\hline \multicolumn{5}{|l|}{ Race } \\
\hline White & 306 & 67.7 & 60.8 & 71.9 \\
\hline Black & 127 & 23.6 & 26.8 & 76.4 \\
\hline Hispanic & 49 & 6.3 & 11.3 & 83.7 \\
\hline Other & 7 & 2.4 & 1.1 & 57.1 \\
\hline \multicolumn{5}{|l|}{ Education } \\
\hline Less than HS & 229 & 38.6 & 49.7 & 78.6 \\
\hline HS Grad or GED & 221 & 48.0 & 44.2 & 72.4 \\
\hline Assoc. Degree & 9 & 2.4 & 1.7 & 66.7 \\
\hline Bachelor's Degree & 21 & 6.3 & 3.6 & 61.9 \\
\hline Professional Degree & 9 & 4.7 & 0.8 & 33.3 \\
\hline \multicolumn{5}{|l|}{ Age at Application } \\
\hline 30 or Younger & 16 & 3.2 & 3.3 & 75 \\
\hline $31-40$ & 52 & 5.5 & 12.4 & 86.5 \\
\hline $41-50$ & 155 & 27.6 & 33.2 & 77.4 \\
\hline $51-60$ & 235 & 54.3 & 45.9 & 70.6 \\
\hline $61 \& U p$ & 31 & 9.5 & 5.3 & 61.3 \\
\hline \multicolumn{5}{|l|}{ Health } \\
\hline Cancers \& tumors; skin conditions & 19 & 3.4 & 2.5 & 68.4 \\
\hline $\begin{array}{l}\text { Musculoskeletal system } \\
\text { \& connective tissue }\end{array}$ & 221 & 34.6 & 30.2 & 71.9 \\
\hline Heart, circulatory \& blood conditions & 213 & 25.1 & 31.9 & 78.9 \\
\hline Respiratory system conditions & 63 & 10.1 & 8.6 & 71.4 \\
\hline Endocrine, metabolic \& nutritional & 48 & 8.4 & 6.3 & 68.8 \\
\hline Digestive system & 34 & 5.0 & 4.8 & 73.5 \\
\hline Neurological \& sensory & 48 & 5.6 & 7.2 & 79.2 \\
\hline Reproductive system \& prostate & 1 & 0.0 & 0.2 & 100.0 \\
\hline Emotional \& psychological & 27 & 2.8 & 4.2 & 81.5 \\
\hline Miscellaneous & 24 & 3.4 & 3.4 & 75.0 \\
\hline Other symptoms & 7 & 1.7 & 0.8 & 57.1 \\
\hline
\end{tabular}

a. This column reports the percent of each category with a given characteristic. (For example, of denied applicants, the percentage who are white.)

b. The sample here is smaller because a number of applicants do not report a date of application

c. Including those accepted on appeal or re-application

d. $57 \%$ of males with no application reported being in the labor force

jected applicants have weaker labor force attachment in each of the years leading up to application. The overall drop from 10 years prior to application until 1 year to application is substantially larger for the rejected group. The drop in earnings is over $\$ 2100$ more and the drop in labor force participation is twice as great. 


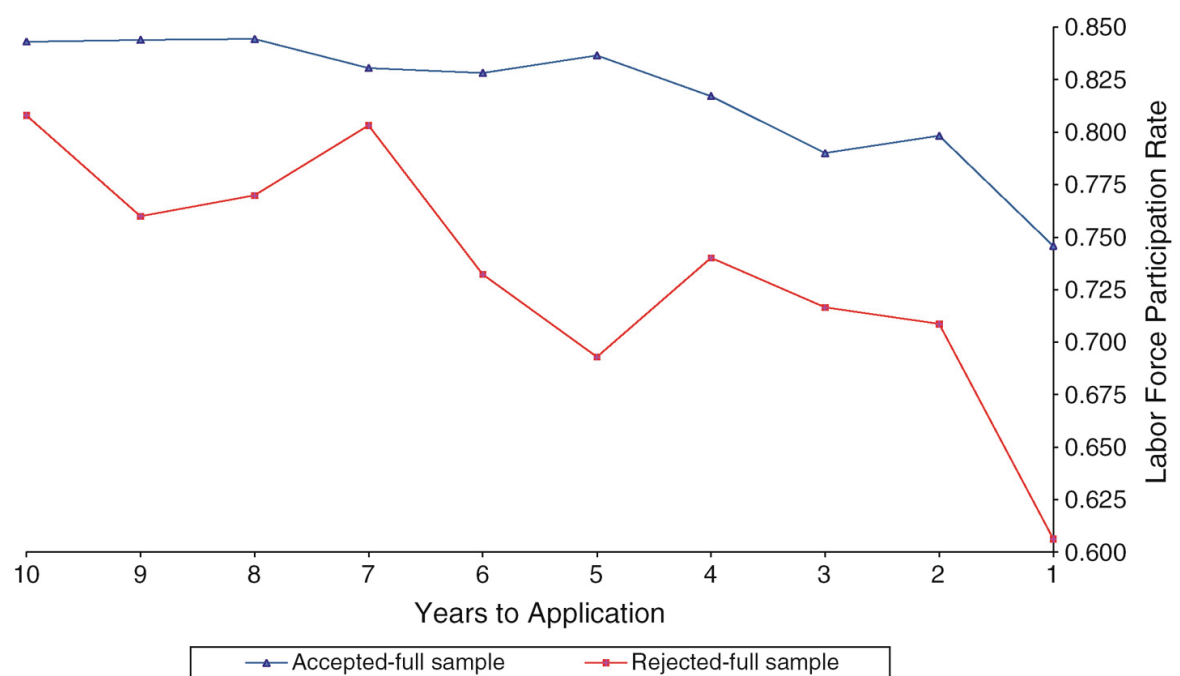

Figure 1. Male labor force participation rates in the years leading to disability application. 1. Calculations are not conditioned on health or demographic characteristics. 2. Individuals with more than $\$ 100$ in earnings are considered in the labor force. 3. Authors' calculations based on HRS data.

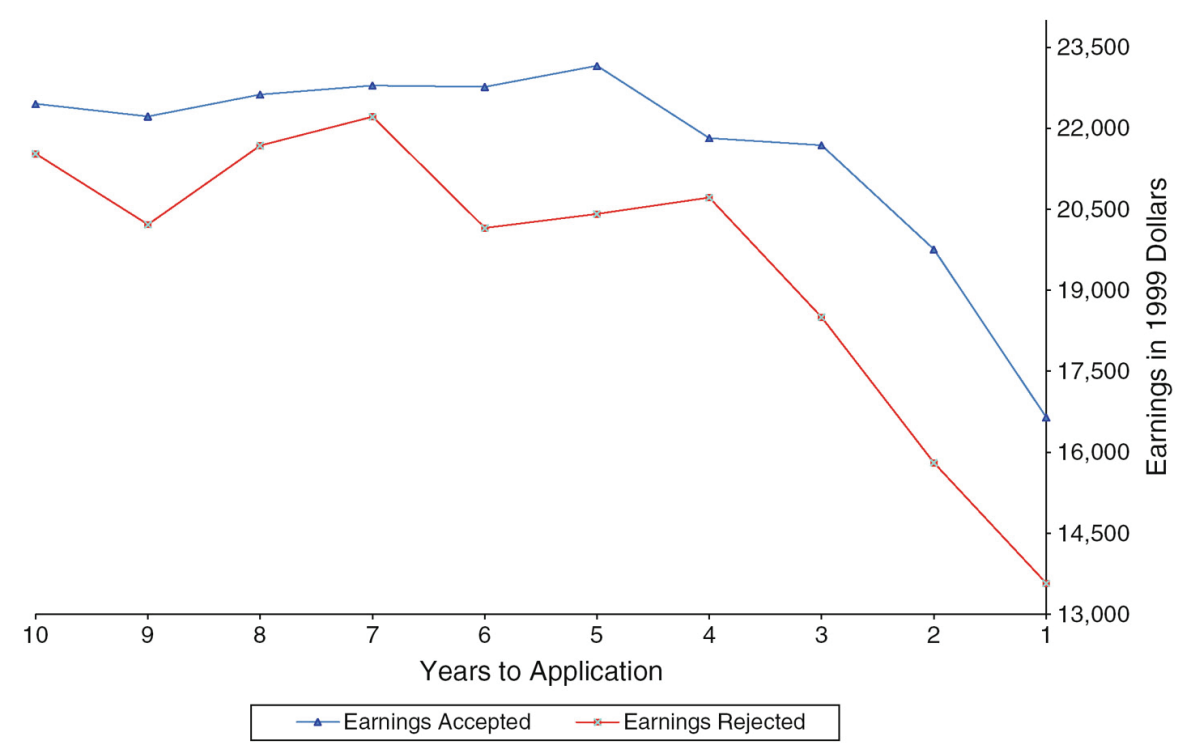

Figure 2. Male earnings in the years leading to disability application. 1. Calculations are not conditioned on health or demographic characteristics. 2. Authors' calculations based on HRS data.

While there are clear labor market behavior differences between the two groups, we want to know how much of these differences can be accounted for by observable differences in demographic and health characteristics between accepted and rejected applicants. It may be that work behavior correlated with 
these demographic variables is responsible for the observed differences between rejected applicants and beneficiaries. Because the type of impairment one acquires is also related to the nature of his job, the group differences may simply reflect the disproportionate rejection rate associated with certain impairments. Unfortunately, our health information is reported in the first (1992) wave of the HRS, while our earnings records span the 1980s. Thus, this health information is time-invariant. While contemporaneous health measures would be preferable, it is likely that there is strong positive correlation between ex post reported health conditions and contemporaneous measures. However, it remains unknown whether this is in fact the case.

To explore these possibilities, a regression analysis is performed. The model we estimate is:

$$
\begin{aligned}
\text { Labor Force Activity }_{i, t}= & \alpha+\delta \text { Rejected Applicant } \\
& + \text { Year to Application Dummies } \\
&
\end{aligned}
$$

where Labor Force Activity A $_{i, t}$ is a measure of person $i$ 's work behavior $t$ years before his disability application. Rejected Applicant $t_{i}$ is an indicator for whether the individual's application for disability benefits was denied by the SSA. Year to Application Dummies $_{i, t}$ is a series of indicators for how many years before disability application we are observing the individual's work behavior. $X_{i}$ is a vector of the individual's demographic and health characteristics listed in Table 3 , and $\varepsilon_{i, t}$ is an error term. The coefficient of interest in this model is $\delta$, which measures whether rejected disability applicants have different average labor market experiences over the 10 years before application than accepted applicants.

The results of the estimation of this model are reported in Table 4. In column (1), the measure of labor force behavior is an indicator for whether the individual worked in the year; no demographic or health controls are included in this specification. The coefficient on the rejection indicator is negative and statistically different from zero at usual levels of significance. Its magnitude suggests that rejected applicants are on average about 8.5 percentage points less likely to be in the labor force in the 10 years leading up to disability application compared to accepted applicants. Because on average about $79.6 \%$ of disability applicants are working in a year during the decade before application, the coefficient implies that rejected applicants are about $10.7 \%$ less likely to be in the labor force than accepted applicants.

In column (2) of Table 4, we present the results of the same regression specification except that we now include the demographic and health controls in the model. The coefficient on the rejection indicator slightly grows in absolute value and is again statistically different from zero. In this model, rejected applicants are about 9 percentage points (about 11.2\%) less likely than accepted applicants to be in the labor force.

The next two columns of Table 4 display the estimation of Equation (1) with the individual's annual labor earnings as the dependent variable. Column (3) shows the results with no demographic and health controls in the model. The coefficient on the rejection indicator is negative, but it is imprecisely estimated. The magnitude of the coefficient suggests that rejected applicants earn on average about $\$ 2100$ less per year than accepted applicants during the decade before 
Table 4. Level effect regression results for male applicants

\begin{tabular}{|c|c|c|c|c|}
\hline & \multicolumn{2}{|c|}{ LFP } & \multicolumn{2}{|c|}{ Earnings } \\
\hline & $\begin{array}{l}\text { No Controls } \\
\text { (1) }\end{array}$ & $\begin{array}{l}\text { With Controls }{ }^{\mathrm{a}} \\
\text { (2) }\end{array}$ & $\begin{array}{l}\text { No Controls } \\
\text { (3) }\end{array}$ & $\begin{array}{c}\text { With Controls }{ }^{\mathrm{a}} \\
\text { (4) }\end{array}$ \\
\hline Rejection Indicator & $\begin{array}{l}-0.0841^{\mathrm{c}} \\
(0.033)\end{array}$ & $\begin{array}{r}-0.0913^{c} \\
(0.0329)\end{array}$ & $\begin{array}{l}-2114.25 \\
(1691.70)\end{array}$ & $\begin{array}{l}-3930.37^{c} \\
(1572.44)\end{array}$ \\
\hline 9 year to Application & $\begin{array}{c}-0.0118 \\
(0.013)\end{array}$ & $\begin{array}{c}-0.0067 \\
(0.0137)\end{array}$ & $\begin{array}{c}-511.495 \\
(382.11)\end{array}$ & $\begin{array}{c}-470.28 \\
(386.43)\end{array}$ \\
\hline 8 year to Application & $\begin{array}{c}-0.0089 \\
(0.015)\end{array}$ & $\begin{array}{c}-0.0029 \\
(0.0161)\end{array}$ & $\begin{array}{l}167.9876 \\
(492.10)\end{array}$ & $\begin{array}{l}-3.41573 \\
(527.51)\end{array}$ \\
\hline 7 year to Application & $\begin{array}{c}-0.0105 \\
(0.016)\end{array}$ & $\begin{array}{c}0.0015 \\
(0.0179)\end{array}$ & $\begin{array}{l}431.4856 \\
(503.99)\end{array}$ & $\begin{array}{l}94.78838 \\
(588.60)\end{array}$ \\
\hline 6 year to Application & $\begin{array}{c}-0.0307 \\
(0.016)\end{array}$ & $\begin{array}{r}-0.0140 \\
(0.0185)\end{array}$ & $\begin{array}{c}-123.247 \\
(538.05)\end{array}$ & $\begin{array}{r}-613.63 \\
(681.17)\end{array}$ \\
\hline 5 year to Application & $\begin{array}{c}-0.0348 \\
(0.018)\end{array}$ & $\begin{array}{c}-0.0147 \\
(0.0213)\end{array}$ & $\begin{array}{l}232.2968 \\
(608.36)\end{array}$ & $\begin{array}{c}-320.866 \\
(810.78)\end{array}$ \\
\hline 4 year to Application & $\begin{array}{c}-0.0368 \\
(0.019)\end{array}$ & $\begin{array}{c}-0.0149 \\
(0.0234)\end{array}$ & $\begin{array}{r}-677.97 \\
(657.05)\end{array}$ & $\begin{array}{r}-1453.69 \\
(928.69)\end{array}$ \\
\hline 3 year to Application & $\begin{array}{c}-0.0630^{c} \\
(0.020)\end{array}$ & $\begin{array}{c}-0.0412 \\
(0.0260)\end{array}$ & $\begin{array}{r}-1354.36^{\mathrm{b}} \\
(695.80)\end{array}$ & $\begin{array}{c}-2346.94^{\mathrm{c}} \\
(1053.45)\end{array}$ \\
\hline 2 year to Application & $\begin{array}{c}-0.0589^{c} \\
(0.021)\end{array}$ & $\begin{array}{c}-0.0449 \\
(0.0299)\end{array}$ & $\begin{array}{r}-3481.51^{\mathrm{c}} \\
(724.59)\end{array}$ & $\begin{array}{c}-4668.91^{\mathrm{c}} \\
(1186.70)\end{array}$ \\
\hline 1 year to Application & $\begin{array}{c}-0.1244^{c} \\
(0.023)\end{array}$ & $\begin{array}{c}-0.1195^{c} \\
(0.0338)\end{array}$ & $\begin{array}{r}-6362.52^{c} \\
(776.45)\end{array}$ & $\begin{array}{l}-7852.25^{c} \\
(1334.82)\end{array}$ \\
\hline Constant & $\begin{array}{l}0.8558^{c} \\
(0.019)\end{array}$ & $\begin{array}{c}0.9255 \\
(0.7688)\end{array}$ & $\begin{array}{r}22759.62^{c} \\
(867.45)\end{array}$ & $\begin{array}{r}1131.831 \\
(20829.13)\end{array}$ \\
\hline
\end{tabular}

a. Year dummies, as well as demographic and health variables were also included in this run

b. Statistically significant at the $10 \%$ level

c. Statistically significant at the $5 \%$ level

application. Average yearly earnings of accepted disability applicants during this period is about $\$ 21,600$, implying that rejected applicants earnings are about $9.7 \%$ lower than beneficiaries before application.

When demographic and (ex post) health controls are added to the model in column (4) of Table 4, the effect of the rejection indicator strengthens. The coefficient is almost twice as large and is statistically different from zero. The magnitude of the coefficient implies that rejected applicants earn almost $\$ 4000$ per year less on average $(18.5 \%)$ than accepted applicants during the decade before application.

The results of the estimation of Equation (1) indicate significant level differences in the labor force activity of rejected and accepted disability applicants during the decade before application. Rejected applicants are less likely to be in the labor force and earn less. Now, we examine whether there is a divergence in the 
labor market activity of rejected applicants compared to accepted applicants during this time period. The estimating equation is now:

$$
\begin{aligned}
& \text { Labor Force Activity }_{i, t}=\alpha+\delta \text { Rejected Applicant }_{i}+\varphi \text { Rejected Applicant }_{i} \\
& \quad \times(- \text { Years to Application } \\
& i, t)
\end{aligned}
$$

where -Years to Application ${ }_{i, t}$ is the negative of the number of years until the individual applies for disability benefits, and the other variables are defined as before. In this model, $\varphi$ is the coefficient of interest, which measures whether there is a linear time trend (i.e., divergence) in the labor force activity of rejected applicants compared to accepted applicants before application.

The results of the estimation of Equation (2) are presented in Table 5. The dependent variable for the first two columns is a dummy variable that equals one if the individual is in the labor force. In column (1), no demographic or health controls are included. The estimated coefficient on the rejection indicator is again large, negative and statistically different from zero. However, the coefficient on the interaction term is negative but imprecisely estimated.

When demographic and health controls are added in column (2), the coefficient on the interaction term increases in absolute value and is now statistically significant from zero. The coefficient implies just over a 1-percentage point (or $1.3 \%$ ) per year divergence of labor force participation rates between accepted and rejected applicants as the application date approaches. (This is in addition to the level differences between the groups.)

The next two columns of Table 5 display the estimation of Equation (2) with annual labor earnings as the dependent variable. Column (3) shows the results with no demographic and health controls. The coefficient on the interaction term is negative but not statistically significant from zero. The coefficient implies that rejected applicant earnings fall by $\$ 278$ (or about 1.2\%) more than accepted earnings in each of the 10 years preceding application. Including demographic and health controls in column (4) yields similar results. This specification implies that rejected earnings fall by about $\$ 264$ more than accepted in each of the years prior to application. Also for this specification, the rejection indicator is large in absolute value. The coefficient suggests a level difference between the two groups of nearly $\$ 5400$.

One possible explanation for the differences in the measured labor market behavior between accepted and rejected disability applicants could be due to a disproportionate share of SSI applicants among the rejected group. Because those qualifying for SSI generally have weak labor force attachment and low earnings, if SSI applicants are more likely to be rejected than DI applicants, then our observed differences in labor market behavior across groups might be only because of this composition effect. To control for this potential problem, our previous analysis is re-estimated using only those with strong attachments to the labor force well before application in the regression sample, all of whom are likely to have applied for DI. ${ }^{15}$

15. A simpler solution would be to look separately at SSI and DI applicants, but the HRS often does not distinguish between applications to the two programs (or if applications were filed for both programs). 
Table 5. Interacted regression results for male applicants

\begin{tabular}{|c|c|c|c|c|}
\hline & \multicolumn{2}{|c|}{ LFP } & \multicolumn{2}{|c|}{ Earnings } \\
\hline & $\begin{array}{c}\text { No Controls } \\
\text { (1) }\end{array}$ & $\begin{array}{c}\text { With Controls }{ }^{\mathrm{a}} \\
\text { (2) }\end{array}$ & $\begin{array}{c}\text { No Controls } \\
\text { (3) }\end{array}$ & $\begin{array}{c}\text { With Controls }{ }^{\mathrm{a}} \\
\text { (4) }\end{array}$ \\
\hline Rejection Indicator & $\begin{array}{c}-0.1231^{\mathrm{d}} \\
(0.0461)\end{array}$ & $\begin{array}{r}-0.1482^{\mathrm{d}} \\
(0.0471)\end{array}$ & $\begin{array}{l}-3641.6^{c} \\
(2077.4)\end{array}$ & $\begin{array}{r}-5387.2^{\mathrm{d}} \\
(2036.7)\end{array}$ \\
\hline Interaction $^{\mathrm{b}}$ & $\begin{array}{c}-0.0071 \\
(0.0055)\end{array}$ & $\begin{array}{r}-0.0103^{c} \\
(0.0055)\end{array}$ & $\begin{array}{c}-278.4 \\
(213.9)\end{array}$ & $\begin{array}{l}-263.9 \\
(217.2)\end{array}$ \\
\hline 9 year to Application & $\begin{array}{c}-0.0099 \\
(0.0135)\end{array}$ & $\begin{array}{l}-0.0037 \\
(0.0137)\end{array}$ & $\begin{array}{l}-438.3 \\
(386.7)\end{array}$ & $\begin{array}{l}-394.0 \\
(389.8)\end{array}$ \\
\hline 8 year to Application & $\begin{array}{c}-0.0052 \\
(0.0158)\end{array}$ & $\begin{array}{l}0.0028 \\
(0.0164)\end{array}$ & $\begin{array}{c}312.4 \\
(503.9)\end{array}$ & $\begin{array}{c}142.7 \\
(539.2)\end{array}$ \\
\hline 7 year to Application & $\begin{array}{c}-0.0050 \\
(0.0170)\end{array}$ & $\begin{array}{c}0.0099 \\
(0.0186)\end{array}$ & $\begin{array}{c}647.5 \\
(526.6)\end{array}$ & $\begin{array}{c}312.1 \\
(605.7)\end{array}$ \\
\hline 6 year to Application & $\begin{array}{c}-0.0233 \\
(0.0172)\end{array}$ & $\begin{array}{c}-0.0028 \\
(0.0192)\end{array}$ & $\begin{array}{l}165.4 \\
(557.4)\end{array}$ & $\begin{array}{l}-326.6 \\
(693.8)\end{array}$ \\
\hline 5 year to Application & $\begin{array}{c}-0.0256 \\
(0.0192)\end{array}$ & $\begin{array}{c}-0.0007 \\
(0.0218)\end{array}$ & $\begin{array}{c}593.4 \\
(635.9)\end{array}$ & $\begin{array}{c}37.6 \\
(828.7)\end{array}$ \\
\hline 4 year to Application & $\begin{array}{l}-0.0258 \\
(0.0206)\end{array}$ & $\begin{array}{c}0.0017 \\
(0.0245)\end{array}$ & $\begin{array}{l}-244.4 \\
(707.8)\end{array}$ & $\begin{array}{r}-1028.4 \\
(965.9)\end{array}$ \\
\hline 3 year to Application & $\begin{array}{c}-0.0501^{\mathrm{d}} \\
(0.0224)\end{array}$ & $\begin{array}{c}-0.0224 \\
(0.0273)\end{array}$ & $\begin{array}{r}-848.7 \\
(745.9)\end{array}$ & $\begin{array}{r}-1864.7^{c} \\
(1083.0)\end{array}$ \\
\hline 2 year to Application & $\begin{array}{r}-0.0442^{c} \\
(0.0233)\end{array}$ & $\begin{array}{c}-0.0242 \\
(0.0310)\end{array}$ & $\begin{array}{r}-2903.6^{\mathrm{d}} \\
(813.9)\end{array}$ & $\begin{array}{r}-4138.3^{\mathrm{d}} \\
(1227.7)\end{array}$ \\
\hline 1 year to Application & $\begin{array}{c}-0.1078^{\mathrm{d}} \\
(0.0256)\end{array}$ & $\begin{array}{r}-0.0978^{\mathrm{d}} \\
(0.0347)\end{array}$ & $\begin{array}{r}-5712.3^{\mathrm{d}} \\
(883.4)\end{array}$ & $\begin{array}{r}-7297.5^{c} \\
(1370.9)\end{array}$ \\
\hline Constant & $\begin{array}{l}0.8475^{\mathrm{d}} \\
(0.0195)\end{array}$ & $\begin{array}{c}0.9038 \\
(0.7639)\end{array}$ & $\begin{array}{r}22433.8^{\mathrm{d}} \\
(889.6)\end{array}$ & $\begin{array}{r}575.5^{\mathrm{d}} \\
(20792.4)\end{array}$ \\
\hline
\end{tabular}

a. Year dummies, as well as demographic and health variables were included in this run

b. Rejection dummy multiplied by the observation year less the application year

c. Statistically significant at the $10 \%$ level

d. Statistically significant at the $5 \%$ level

Individuals with less than $\$ 10,000$ per year in real earnings 7 years prior to application are dropped. ${ }^{16}$ This reduces the sample size to 315 accepted (of which 253 report an application date) and 157 rejected (of which 75 report an application date). The regression analysis is repeated with this sub-sample. Now we only examine the earnings and labor force participation decisions of applicants during the 6 years before application. A similar pattern emerges, but this time, especially when examining labor force participation, the evidence of divergence over time between accepted and rejected applicants is much stronger. This suggests that the earlier results were not driven by a disproportionate presence of SSI applicants among the rejected group.

16. A similar analysis was also tried keeping only those with $\$ 10,000$ or more in earnings for the seven through 10 years prior to application. This analysis yielded similar results. 
Table 6. Restricted sample regression results (with interactions) for male applicants

\begin{tabular}{lccccc}
\hline & \multicolumn{2}{c}{ LFP } & & \multicolumn{2}{c}{ Earnings } \\
\cline { 2 - 3 } \cline { 5 - 6 } & $\begin{array}{c}\text { No Controls } \\
(1)\end{array}$ & $\begin{array}{c}\text { With Controls } \\
(2)\end{array}$ & & $\begin{array}{c}\text { No Controls } \\
(3)\end{array}$ & $\begin{array}{c}\text { With Controls } \\
(4)\end{array}$ \\
\hline Rejection Indicator & $-0.1761^{\mathrm{e}}$ & $-0.2032^{\mathrm{e}}$ & & -3110.31 & $-5681.7^{\mathrm{e}}$ \\
& $(0.0605)$ & $(0.0612)$ & & $(2956.13)$ & $(2875.5)$ \\
Interactionc & $-0.0241^{\mathrm{e}}$ & $-0.0282^{\mathrm{e}}$ & & -666.21 & -617.0 \\
& $(0.0106)$ & $(0.0106)$ & & $(474.63)$ & $(498.8)$ \\
& $-0.0282^{\mathrm{e}}$ & $-0.0275^{\mathrm{e}}$ & & -302.77 & -550.0 \\
5 year to Application & $(0.0136)$ & $(0.0137)$ & & $(523.11)$ & $(546.0)$ \\
& $-0.0472^{\mathrm{e}}$ & $-0.0459^{\mathrm{e}}$ & & -1600.20 & $-2332.1^{\mathrm{e}}$ \\
& $(0.0153)$ & $(0.0165)$ & & $(678.06)$ & $(755.5)$ \\
3 year to Application to Application & $-0.0537^{\mathrm{e}}$ & $-0.060^{\mathrm{e}}$ & & $-2361.47^{\mathrm{e}}$ & $-3575.4^{\mathrm{e}}$ \\
& $(0.0185)$ & $(0.0209)$ & & $(796.15)$ & $(933.3)$ \\
2 year to Application & $-0.0849^{\mathrm{e}}$ & $-0.0991^{\mathrm{e}}$ & & $-5296.00^{\mathrm{e}}$ & $-6792.3^{\mathrm{e}}$ \\
& $(0.0198)$ & $(0.0237)$ & & $(935.60)$ & $(1146.7)$ \\
1 year to Application & $-0.1344^{\mathrm{e}}$ & $-0.1534^{\mathrm{e}}$ & & $-8892.20^{\mathrm{e}}$ & $-10914.2^{\mathrm{e}}$ \\
& $(0.0229)$ & $(0.0278)$ & & $(1092.89)$ & $(1389.8)$ \\
Constant & 0.9918 & 1.0649 & $31131.54^{\mathrm{e}}$ & 36730.1 \\
& $(0.0084)$ & $(1.0033)$ & $(935.95)$ & $(46924.2)$ \\
\hline
\end{tabular}

a. Those with $\$ 10,000$ or more earnings 7 years prior to application

b. Year dummies, as well as demographic and health variables were included in this run

c. Rejection dummy multiplied by the observation year less the application year

d. Statistically significant at the $10 \%$ level

e. Statistically significant at the $5 \%$ level

Columns (1) and (2) of Table 6 report the labor force participation results. The interaction coefficient as well as the rejection indicator are negative and are statistically different from zero (for both the specification with and without health and demographic controls). The estimates are much larger in absolute value than the estimates from the unrestricted sample in Table 5. With health and demographic controls, the coefficient on the interacted term implies an over 2.8 percentage point (or 3.4\%) per year divergence between accepted and rejected applicants, as the application date approaches. (This is in addition to an over 20-percentage point (nearly $25 \%$ ) level difference between the groups.)

Columns (3) and (4) of Table 6 present the results for the earnings regressions with the restricted sample. As with labor force participation, the earnings results are now much larger in absolute value; however, as with the full sample, the coefficients on the interaction terms are still imprecisely estimated. With health and demographic controls, the interacted coefficient implies a divergence of over $\$ 600$ (or 2.9\%) for each of the 6 years prior to application. Also with the controls, the coefficient on the rejection dummy is large in absolute value and shows strong statistical significance. It suggests a close to $\$ 5700$ (or over $27 \%$ ) level difference between the groups. 


\section{Conclusion}

Disability Insurance and Supplemental Security Income caseloads have increased rapidly in the United States over the past 30 years. The rapid growth of these federal disability programs has been criticized on the grounds that imperfect targeting causes able individuals to use the programs to subsidize early retirement. This criticism has given rise to a large literature on the effects of disability benefits on labor force participation; however, there has been little work analyzing how the disability screening process actually separates applicants.

Our results suggest that rejected and accepted disability applicants have different labor market experiences in the years prior to application. Rejected applicants are less likely to be in the labor force and earn less than beneficiaries during the decade before application. There is some evidence that these differences grow larger as the date of application approaches, especially for applicants with a past strong labor market attachment who are most likely to have applied for DI. The data clearly show that denied applicants are likely to experience more pronounced declines in earnings and labor force participation before application than beneficiaries.

There is considerable evidence from other work that people's economic circumstances affect the decision whether or not they apply for disability benefits. Studies such as von Wachter et al. (forthcoming), Duggan and Imberman (2008), Autor and Duggan (2003) and Black et al. (2002) find that those who have experienced adverse wage and employment shocks are more likely to apply for benefits. Our work indicates that these applicants are less likely to survive the SSA screening process.

\section{References}

Autor D, Duggan M (2003) The rise in the disability rolls and the decline in unemployment. Q J Econ 118 (1):157-206

Autor D, Duggan M (2006) The growth in the social security disability rolls: a fiscal crisis unfolding. J Econ Perspect 20(3):71-94

Benitez-Silva H, Buchinsky M, Chan HM, Rust J, Sheidvasser S (1999) An empirical analysis of the social security disability application, appeal and award process. Labour Econ 6:147-178

Black D, Daniel K, Sanders S (2002) The impact of economic conditions on participation in disability programs: Evidence from the coal boom and bus. Am Econ Rev 92(1):27-50

Bound J (1989) The health and earnings of rejected disability applicants. Am Econ Rev 79:482-503

Bound J (1991) The health and earnings of rejected disability applicants: Reply. Am Econ Rev 81:1427- 1434

Bound J, Burkhauser R (1999) The economic analysis of transfer programs targeted on people with disabilities. Handb Labor Econ 3:3417-3528

Brooks A (2007) SSI Annual Statistical Report, 2006. Social Security Administration: Division of SSI Statistics and Analysis, Office of Research, Evaluation, and Statistics, Office of Policy

Chen S, van der Klaauw W (2008) The effect of disability insurance on labor supply of older individuals in the 1990s. J Econometrics 142(2):757-784 
Duggan M, Imberman S (2008) Why are the DI rolls skyrocketing? In: David Cutler \& David Wise (eds.) Health at Older Ages: The Causes and Consequences of Declining Disability among the Elderly. University of Chicago Press, Chicago

Gruber J, Kubik J (1997) Disability insurance rejection rates and the labor supply of older workers. J Public Econ 64:1-23

Kreider B, Riphahn R (1999) Explaining applications to the U.S. Disability program: A semi-parametric approach. J Hum Resour 35:82-115

Lahiri K, Vaughan DR, Wixon B (1995) Modeling SSA's sequential disability determination process using matched SIPP data. Soc Secur Bull 58:3-42

Nagi Saad (1969) Disability and Rehabilitation: Legal, Clinical and Self-Concepts and Measurement. Ohio State University Press, Columbus

Parsons D (1991) The health and earnings of rejected disability insurance applicants: comment. Am Econ Rev 81:1419-26

Smith RT, Lilienfeld AM (1971) The Social Security Disability Program: An Evaluation Study. Social Security Administration, Office of Research and Statistics, Research Report No. 39

Social Security Administration (2006) Annual Statistical Supplement to the Social Security Bulletin. Office of Policy, Office of Research, Evaluation, and Statistics

von Wachter T, Song J, Manchester J (forthcoming) Trends in employment and earnings of allowed and rejected applicants to the social security disability insurance program. American Economic Review 